\title{
Genetic Diversity and a PCR-Based Method for Xanthomonas axonopodis Detection in Passion Fruit
}

\author{
C. F. Munhoz, B. Weiss, L. R. Hanai, M. I. Zucchi, M. H. P. Fungaro, \\ A. L. M. Oliveira, C. B. Monteiro-Vitorello, and M. L. C. Vieira
}

First, second, third, seventh, and eighth authors: Universidade de São Paulo, Escola Superior de Agricultura "Luiz de Queiroz", Departamento de Genética, P.O. Box 83, 13400-970 Piracicaba, Brazil; fourth author: Instituto Agronômico, P.O. Box 28, 13012-970 Campinas, Brazil; and fifth and sixth authors: Universidade Estadual de Londrina, P.O. Box 6001, 86051-970 Londrina, Brazil.

Current address of L. R. Hanai: Dow AgroSciences no Brasil, Rodovia Anhanguera Km 296, Cravinhos, Brazil. Accepted for publication 9 November 2010.

\begin{abstract}
Munhoz, C. F., Weiss, B., Hanai, L. R., Zucchi, M. I., Fungaro, M. H. P., Oliveira, A. L. M., Monteiro-Vitorello, C. B., and Vieira, M. L. C. 2011. Genetic diversity and a PCR-based method for Xanthomonas axonopodis detection in passion fruit. Phytopathology 101:416-424.

Xanthomonas axonopodis pv. passiflorae causes bacterial spot in passion fruit. It attacks the purple and yellow passion fruit as well as the sweet passion fruit. The diversity of 87 isolates of pv. passiflorae collected from across 22 fruit orchards in Brazil was evaluated using molecular profiles and statistical procedures, including an unweighted pair-group method with arithmetical averages-based dendrogram, analysis of molecular variance (AMOVA), and an assigning test that provides information on genetic structure at the population level. Isolates from

reaction profile. Amplified fragment length polymorphism technique revealed considerable diversity among isolates of pv. passiflorae, and AMOVA showed that most of the variance (49.4\%) was due to differences between localities. Cluster analysis revealed that most genotypic clusters were homogeneous and that variance was associated primarily with geographic origin. The disease adversely affects fruit production and may kill infected plants. A method for rapid diagnosis of the pathogen, even before the disease symptoms become evident, has value for producers. Here, a set of primers (Xapas) was designed by exploiting a singlenucleotide polymorphism between the sequences of the intergenic 16S23S rRNA spacer region of the pathovars. Xapas was shown to effectively detect all pv. passiflorae isolates and is recommended for disease diagnosis in passion fruit orchards.
\end{abstract} another eight pathovars were included in the molecular analyses and all were shown to have a distinct repetitive sequence-based polymerase chain
Additional keywords: molecular diagnosis, Passiflora.
The bacterium Xanthomonas axonopodis belongs to a group of gram negative, yellow-pigmented plant pathogens that are known to cause significant damage to a variety of commercially important crops. For example, X. axonopodis pv. passiflorae, as proposed by Gonçalves and Rosato (6), formerly X. campestris pv. passiflorae (Pereira 1969) Dye 1978b (22), is responsible for bacterial leaf spot in passion fruit, a disease that has spread rapidly since it was first observed in Brazil in the early 1970s. It affects leaves and fruit, leading to commercial losses, particularly under high-temperature and high-humidity conditions. The pathogen attacks the purple (Passiflora edulis) and the yellow $(P$. edulis f. flavicarpa) forms of passion fruit as well as the sweet passion fruit ( $P$. alata). Chemical controls have produced inconsistent results. In Brazil, passion fruit grown and harvested on small farms using family labor constitutes a significant portion of all fruit produced for local consumption and commercial sale. Although the demand for aromatic passion fruit juice in the European and American markets is very encouraging, the occurrence of bacterial leaf spot makes production unreliable, thus hampering the consistency of exports $(28,32)$. Controlling the disease through the development of resistant varieties is one promising solution to this problem.

Ongoing research has focused on the construction of $P$. edulis $\mathrm{f}$. flavicarpa linkage maps $(2,19)$. Particular attention was given to

Corresponding author: M. L. C. Vieira; E-mail address: mlcvieir@esalq.usp.br

doi:10.1094/PHYTO-06-10-0169

(c) 2011 The American Phytopathological Society bacterial resistance characteristics in the mapping population, leading to the detection of at least one quantitative resistance locus that explained $16 \%$ of the total phenotypic variation for the diseased leaf area (15). The assessment of genetic diversity within a pathogen collection obtained from different locations would also be helpful in understanding effective pathogen resistance in host species. Repetitive sequence-based polymerase chain reaction (rep-PCR) and amplified fragment length polymorphism (AFLP) techniques were useful for characterizing $X$. axonopodis population structures $(24,27)$. The large number of loci (bands) revealed by the AFLP technique provide substantial information about the genetic relatedness of isolates as well as the structure from each planting region (14).

Through early diagnosis of $X$. axonopodis pv. passiflorae infection, growers may be able to take action to avoid serious losses and to reduce spreading of the disease. PCR-based techniques are fast and sensitive and can be utilized by diagnostic laboratories to detect disease symptoms in commercial fresh fruit, plants, and seedlings even before they are visibly evident. For instance, specific primers for PCR detection of X. axonopodis pv. citri, which causes the citrus canker disease, were developed by sequencing of the intergenic 16S-23S rRNA internal transcribed spacer (ITS) region (3).

The objectives of this study were to (i) establish a collection of $X$. axonopodis pv. passiflorae obtained from different geographic locations in Brazil; (ii) measure the genetic diversity within the collection using the AFLP technique; (iii) infer details of the structure of the bacterial population, assigning every isolate to a subpopulation or cluster; and (iv) construct PCR primers based on the analysis of the ITS region of $16 \mathrm{~S}-23 \mathrm{~S}$ rRNA for pathovar 
diagnostic purposes. Two methods that are generally applied to eukaryotic studies were successfully used in this study.

\section{MATERIALS AND METHODS}

Establishing the bacterial collection. A collection of $87 \mathrm{X}$. axonopodis pv. passiflorae isolates was established, with most specimens originating from different commercial orchards of yellow passion fruit. This is the largest collection of Xanthomonas isolates causing leaf spot in passion fruit. Some of the organisms were obtained from the Culture Collection of Phytopathogenic Bacteria of the Biological Institute (IBSBF, Campinas, Brazil), as were seven isolates belonging to seven pathovars of $X$. axonopodis. Two additional isolates of the pathovar $X$. phaseoli were obtained from the Instituto Agronômico (IAC, Campinas, Brazil) (Table 1). To isolate bacteria from the infected leaves, an injured area was surface sterilized in $70 \%$ ethanol and $2 \% \mathrm{NaClO}$ solutions for $2 \mathrm{~min}$ each, followed by a 2-min wash in autoclaved, distilled water. Each sample was sliced with a surgical blade on a plastic plate containing $0.5 \mathrm{ml}$ of water. After $30 \mathrm{~min}, \approx 0.2 \mathrm{ml}$ of the liquid solution from the plate, containing any exuded bacteria, was plated onto general medium nutrient agar (NA) (8 $g$ of peptone, $3 \mathrm{~g}$ of meat extract, $15 \mathrm{~g}$ of agar, water-quantum sufficit $1,000 \mathrm{ml}, \mathrm{pH}$ 7.0). Bacteria were grown at $28^{\circ} \mathrm{C}$ for $48 \mathrm{~h}$.

Yellow-colored colonies of convex shape, shiny, and highly mucoid were analyzed for the presence of xanthomonadins, which are membrane-bound pigments unique to the genus Xanthomonas. Following the protocol of Starr and Stephens (26), the extraction was performed in methanol $\left(90^{\circ} \mathrm{C}\right.$ for $\left.10 \mathrm{~min}\right)$, a very efficient way of extracting these pigments. The presence of xanthomonadins in aliquots of the resulting yellow and translucent solutions was detected by monitoring absorbance at 401 to $500 \mathrm{~nm}$ at regular intervals of every $3 \mathrm{~nm}$. The absorption spectrum of xanthomonadins shows a characteristic structure, with a peak at $\approx 445 \mathrm{~nm}$ and shoulders at 425 and $470 \mathrm{~nm}$.

Pathogenicity test. The pathogenicity of the isolates was confirmed by artificial leaf inoculations of a susceptible passion fruit genotype. Isolates were grown at $28^{\circ} \mathrm{C}$ for $48 \mathrm{~h}$ as described above. The plates were flooded with a $0.85 \% \mathrm{NaCl}$ solution and a bacterial suspension was obtained by scraping the surface of the plates. The suspension was adjusted to an optical density of 0.3 at $600 \mathrm{~nm}$, which corresponds to an approximate bacterial concentration of $10^{8} \mathrm{CFU} / \mathrm{ml}$. Then, cotton swabs were dipped in the bacterial suspensions and spread across the surfaces of a hole made in the leaves with a cork borer. Two leaves were inoculated with each isolate and control plants received only the $0.85 \% \mathrm{NaCl}$ solution. Plants were kept in a greenhouse and disease assessment was done 15 days after inoculation.

DNA extraction. Colonies for DNA extraction were cultivated in liquid nutrient medium. A simple extraction procedure using sodium dodecyl sulfate (SDS) and proteinase K was adopted (1). Aliquots $(1 \mathrm{ml})$ from the liquid cultures were used to preserve bacterial isolates in $60 \%$ glycerol at $-80^{\circ} \mathrm{C}$. DNA samples were stained with ethidium bromide $(5 \mu \mathrm{g} / \mathrm{ml})$, visualized under $\mathrm{UV}$, quantified in comparison with the fluorescent yield of the standards (lambda DNA) after $0.8 \%$ gel electrophoresis $\left(3 \mathrm{~V} \mathrm{~cm}^{-1}\right)$, and photographed using a MultiDoc-It-UVP (UVP LLC, Upland, CA).

TABLE 1. List of Xanthomonas axonopodis according to the pathovar, isolate code, geographic origin, and plant host

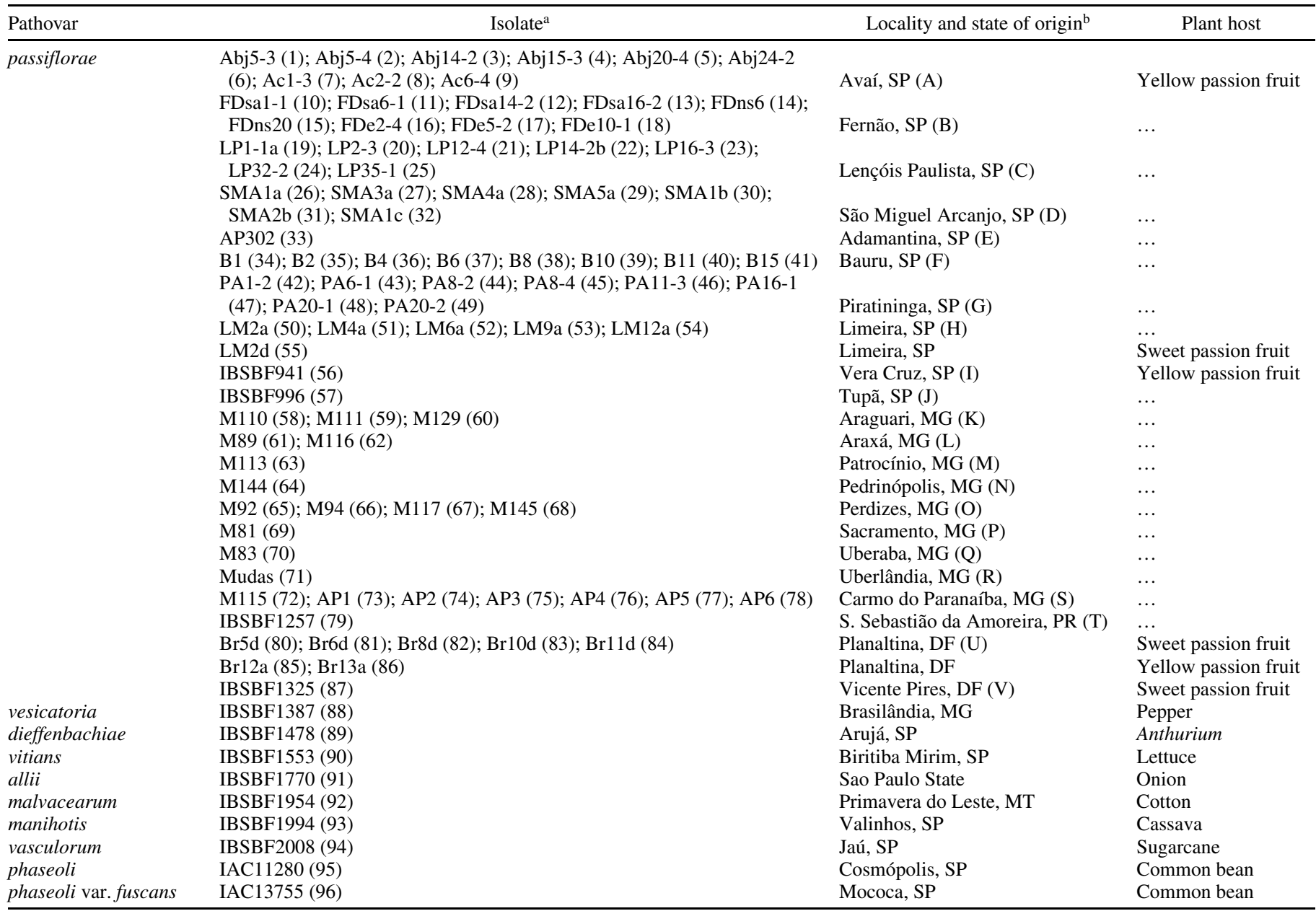

a Numbers within parentheses refer to bacterial isolates or pathovars.

${ }^{b}$ Letters within parentheses refer to localities of origin. 
Rep-PCR. Repetitive DNA sequences known as BOX, ERIC, and REP are currently used for bacterial fingerprinting, including the distinction of closely related plant pathovars. Isolates of $X$. axonopodis pv. passiflorae as well as all different pathovars of $X$. axonopodis were submitted for PCR analysis with the following primer sets (17): BOXA1R (5'-CTACGGCAAGGCGACGC TGACG-3'); ERIC1R (5'-ATGTAAGCTCCTGGGGATTCAC-3') and ERIC2 (5'-AAGTAAGTGACTGGGGTGAGCG-3'); and REP1R-I (5'-IIIICGICGICATCIGGC-3') and REP2-I (5'-ICGI CTTATCIGGCCTAC-3'). A 20- $\mu$ l mixture used to amplify REP and ERIC elements contained $1 \times$ reaction buffer, $1.2 \mu \mathrm{M}$ each primer, $0.4 \mathrm{mM}$ each dNTP, $4 \mathrm{mM} \mathrm{MgCl}_{2}, 1.5 \mathrm{U}$ of Go Taq Flexi Promega Corp. (Madison, WI), and 50 ng of template DNA. For the BOX element, the same mixture was used with the following modifications: $2.0 \mu \mathrm{M}$ primer, $0.5 \mathrm{mM}$ each $\mathrm{dNTP}$, and $2 \mathrm{U}$ of enzyme. PCR conditions were as follows: $95^{\circ} \mathrm{C}$ for $7 \mathrm{~min} ; 30$ cycles at $94^{\circ} \mathrm{C}$ for $1 \mathrm{~min}, 44,52$, or $53^{\circ} \mathrm{C}$ for the REP, ERIC, and BOX primers, respectively, for $1 \mathrm{~min}$, and $72^{\circ} \mathrm{C}$ for $1.5 \mathrm{~min}$; and a final extension at $72^{\circ} \mathrm{C}$ for $15 \mathrm{~min}$, in a Gen Amp PCR System 9700 thermocycler (Applied Biosystems, Carlsbad, CA). Amplicons were electrophoresed in agarose gel (1.4\%) at $3 \mathrm{~V} \mathrm{~cm}^{-1}$, visualized under UV after DNA stained with ethidium bromide $(5 \mu \mathrm{g} / \mathrm{ml})$, and photographed in a MultiDoc-It-UVP.

AFLP. The protocol described by Lopes et al. (15) and modified from Vos et al. (29) was used to obtain the AFLP markers. Briefly, $250 \mathrm{ng}$ of genomic DNA from each isolate was double digested with EcoRI (NE Biolabs, Ipswich, MA) and MseI (Promega Corp.) enzymes (6 U of each) in a solution with $1 \times$ One Phor-All buffer (Amersham Biosciences, Buckinghamshire, United Kingdom), $1 \times$ bovine serum albumen (NE Biolabs), and ultrapure water q.s.p. $20 \mu \mathrm{l}$. Reactions occurred during $4 \mathrm{~h}$ at $37^{\circ} \mathrm{C}$ and then were terminated by heat inactivation $\left(65^{\circ} \mathrm{C}\right.$ for $20 \mathrm{~min}$ ). All resulting fragments were ligated to adapter sequences by adding $1 \times$ T4 DNA ligase reaction buffer, $0.25 \mu \mathrm{M}$ EcoRI adapter (denoted E), $2.5 \mu \mathrm{M}$ MseI adapter (denoted M), $67 \mathrm{U}$ of T4 DNA ligase (NE Biolabs), and ultrapure water q.s.p. $20 \mu \mathrm{l}$. Ligation reactions were incubated at $16^{\circ} \mathrm{C}$ for $14 \mathrm{~h}$ and terminated as described above. Primers, complementary to the adapters, with zero, one, or two selective nucleotides at the $3^{\prime}$ end were used for selective amplification. The 20- $\mu$ l PCR mix contained $1 \times$ reaction buffer, $0.25 \mu \mathrm{M}$ each primer, $0.25 \mathrm{mM}$ each dNTP, $1.5 \mathrm{mM} \mathrm{MgCl}_{2}, 1 \mathrm{U}$ of Go Taq Flexi Promega Corp., and $5 \mu \mathrm{l}$ of the adapter-ligated DNA (diluted fourfold). PCR conditions were as follows: $94^{\circ} \mathrm{C}$ for $2 \mathrm{~min} ; 26$ cycles at $94^{\circ} \mathrm{C}$ for $1 \mathrm{~min}, 56^{\circ} \mathrm{C}$ for $1 \mathrm{~min}$, and $72^{\circ} \mathrm{C}$ for $1 \mathrm{~min}$; and a final extension at $72^{\circ} \mathrm{C}$ for $5 \mathrm{~min}$ in a Gen Amp PCR System 9700 thermocycler. Samples $(2 \mu \mathrm{l})$ of amplified products were denatured with $1 \times$ loading buffer $(0.2 \%$ each of bromophenol blue and xylene cyanol, $10 \mathrm{mM}$ EDTA, and $95 \%$ formamide at $\mathrm{pH} 8.0$ ) at $95^{\circ} \mathrm{C}$ for $5 \mathrm{~min}$ before they were loaded onto the gels. AFLP bands were resolved in 5\% (wt/vol) denaturing polyacrylamide gels (19:1; acrylamide:bis-acrylamide) using the electrophoresis apparatus Sequi-Gen GT (Bio-Rad, Hercules, CA) for $4 \mathrm{~h}$ at $80 \mathrm{~W}$, and visualized by silver staining.

Statistical treatment of AFLP data. Data were scored for the presence $(=1)$ or absence $(=0)$ of amplification products by means of indicator variables. This type of scoring was done for each polymorphic locus across all 87 isolates of $X$. axonopodis pv. passiflorae. Pairwise comparisons of isolates based on shared and unshared amplicons were used to generate similarity coefficients (12). Dendrograms were generated based on the unweighted pairgroup method with arithmetical averages (UPGMA), employing the sequential, agglomerative, hierarchic, and nonoverlapping (SAHN) clustering methods. The statistical package NTSYS-PC software (version 2.1; Setauket, NY) (25) was used for computations. Bootstrap analysis with 1,000 resamples was completed with WINBOOT software (International Rice Research Institute, Manila, Philippines) to determine the confidence limits of the UPGMA dendrogram. "Goodness" of the dendrogram was verified by direct comparison of the original similarity matrix and the cophenetic value matrix derived from the dendrogram, as described by Rohlf (25).

Analysis of molecular variance (AMOVA) was used to estimate the components of variation directly from AFLP data, using ARLEQUIN software (version 2.000; Genetic and Biometry Laboratory, University of Geneva, Switzerland). Total variation was subdivided, reflecting variation between the geographical Brazilian states, between the localities within each of the states, and within the localities.

Each isolate was probabilistically assigned to a genetically distinct cluster based on Bayesian models using STRUCTURE software (version 2.2.3; Department of Human Genetics, University of Chicago) (23), available online from Cornell University at http://cbsuapps.tc.cornell.edu/structure.aspx. This package allowed us to assess the genetic structure of the $X$. axonopodis $\mathrm{pv}$. passiflorae collection assuming that all sampled isolates belong to an unknown number of clusters $(K)$ that are defined by the means of the frequency of AFLP bands. The $K$ statistic, which is based on the rate of chance in the log probability of data between successive $K$ values (5), was calculated. Ten runs were performed for each number of clusters ( $K$ of 1 to 22, a burn-in of 200,000 and 300,000 Markov chain-Monte Carlo steps after the burn-in period). This analysis indicated the number of clusters that best fit the data.

Sequencing of the intergenic 16S-23S rRNA ITS region. The intergenic 16S-23S rRNA spacer region of four isolates of pv. passiflorae (Abj20-4, LP1-1a, PA6-1, and Br5d; GenBank accession nos. FJ828864, FJ828866, FJ828867, and FJ828865, respectively) and eight pathovars of $X$. axonopodis (IBSBF1387, IBSBF1478, IBSBF1553, IBSBF1770, IBSBF1954, IBSBF1994,
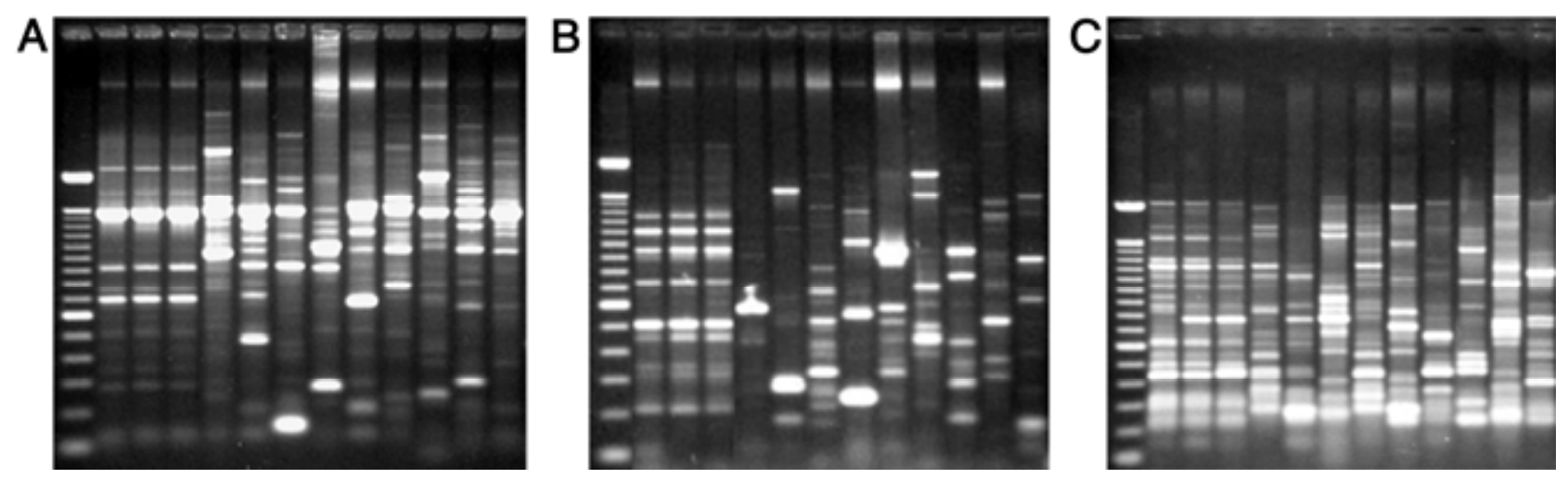

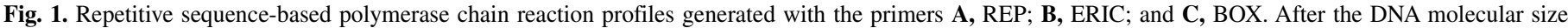

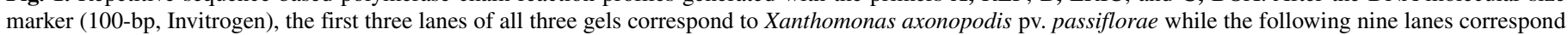
to other pathovars of $X$. axonopodis (Table 1, 88 to 96). 
IBSBF2008, and IAC13755; GenBank accession nos. FJ828868, FJ828869, FJ828870, FJ828871, FJ828872, FJ828873, FJ828874, and FJ828875, respectively) was amplified using the primer pair pHr 5'-TGCGGCTGGATCACCTCCTT-3' (18) and p23Suni322anti 5'-GGTTCTTTTCACCTTTCCCTC-3' (10). PCR was conducted using a thermocycler PTC-100 (MJ Research, Inc., Waltham, MA) as described previously (20), except that the annealing temperature was $58^{\circ} \mathrm{C}$. PCR products were precipitated with polyethylene glycol and ethanol, and sequenced using the DYEnamic ET dye terminator Cycle Sequencing kit (Amersham Biosciences) with the abovementioned primers. Reactions were carried out in a Mastercycler Gradient thermocycler (Eppendorf, Hamburg, Germany) and electrophoresed in a MegaBace 1000 Molecular Dynamics sequencer (Amersham Biosciences). Sequences were assembled using the Phred/Phrap/ Consed package (University of Washington, Seattle) applying a quality threshold value $\geq 20$. If the Phred score of a base exceeded this threshold, the base was considered high quality.

Sequence alignment and primer designing. The ITS sequences were initially aligned using Clustal X Software (version 1.81; Rockville Pike, Bethesda, MD). Nucleotide differences among the aligned sequences were visually searched and a singlenucleotide polymorphism (SNP) of interest was detected. A threeprimer set was designed and included a forward (Xapas-F), an outer reverse (Xapas-Ro), and an inner reverse (Xapas-Ri) primer. To enhance pathovar specificity, a second deliberate mismatch (an A instead of a $G$ nucleotide) at position -2 from the 3 ' end of the inner primer was also incorporated, as suggested by Ye et al. (31). The primers were mixed to amplify two bands. Xapas-F and Xapas-Ro produce a larger and common band because both anneal to conserved sequences in all pathovars, whereas Xapas-F and Xapas-Ri produce a smaller band specific to pv. passiflorae allele because the Xapas-Ri 3'-terminal base was positioned at the SNP. The GeneRunner program (http://www.generunner.com) was used to calculate the primer melting temperatures as the percentage of GC, and also determine the formation of secondary structures like hairpins, dimers, and loops within primer sequences.

For primer validation, all 87 isolates from pv. passiflorae, nine from other pathovars of $X$. axonopodis, and one isolate of $X$. campestris pv. campestris were used. The 20- $\mu$ l PCR mix contained $1 \times$ reaction buffer (Promega Corp.), $1 \mu \mathrm{M}$ inner primer, $0.1 \mu \mathrm{M}$ outer reverse primer, $0.1 \mu \mathrm{M}$ forward primer, $0.2 \mathrm{mM}$ each dNTP, $2.0 \mathrm{mM} \mathrm{MgCl} 2,1 \mathrm{U}$ of Go Taq Flexi (Promega Corp.), and $40 \mathrm{ng}$ of template DNA. PCR conditions were as follows: $94^{\circ} \mathrm{C}$ for $3 \mathrm{~min}$; 35 cycles of $94^{\circ} \mathrm{C}$ for $1 \mathrm{~min}, 58^{\circ} \mathrm{C}$ for $1 \mathrm{~min}$, and $72^{\circ} \mathrm{C}$ for $1 \mathrm{~min}$; and a final extension of $72^{\circ} \mathrm{C}$ for 5 min in a Gen Amp PCR System 9700 thermocycler. Amplicons were electrophoresed at $3 \mathrm{~V} \mathrm{~cm}^{-1}$ and visualized under UV after DNA SYBR Safe (Invitrogen, Carlsbad, CA) (0.5x) staining; photographs were taken to document results.

A bioassay for detection and quantification of $X$. axonopodis pv. passiflorae in plant tissues. Inoculums were produced by growing the Abj5-3 isolate on NA as previously described. The plates were flooded with a $0.85 \% \mathrm{NaCl}$ solution and a bacterial suspension was obtained by scraping the surface of the plates. The suspension was adjusted to an optical density of 0.3 at $600 \mathrm{~nm}$, which corresponds to an approximate bacterial concentration of $10^{8} \mathrm{CFU} / \mathrm{ml}$.

Inoculations were performed by cutting off a 2-cm strip from the tip of fully expanded leaves with a pair of scissors that had been immersed in the bacterial suspension. Three leaves of each of three 120 day-old plants of $P$. alata were inoculated (a total of nine inoculations). A control plant received only the $0.85 \% \mathrm{NaCl}$ solution. Plants were kept in a greenhouse under controlled conditions of temperature (minimum temperature of $13 \pm 2^{\circ} \mathrm{C}$ and maximum temperature of $30 \pm 2^{\circ} \mathrm{C}$ ) and humidity (minimum of 14 to $18 \%$ and maximum of 88 to $99 \%$ ). One leaf was collected on days 5,12 , and 19 post inoculation, and each leaf was separated into two halves. One half was used for quantifying $X$. axonopodis pv. passiflorae by reisolating and direct counting of CFU using a single dilution series; the other half was further subdivided into two more segments, proximal and distal to the inoculation point, to determine possible bacterial migration. These segments were used for DNA extraction (4), with $60 \mathrm{ng}$ of DNA

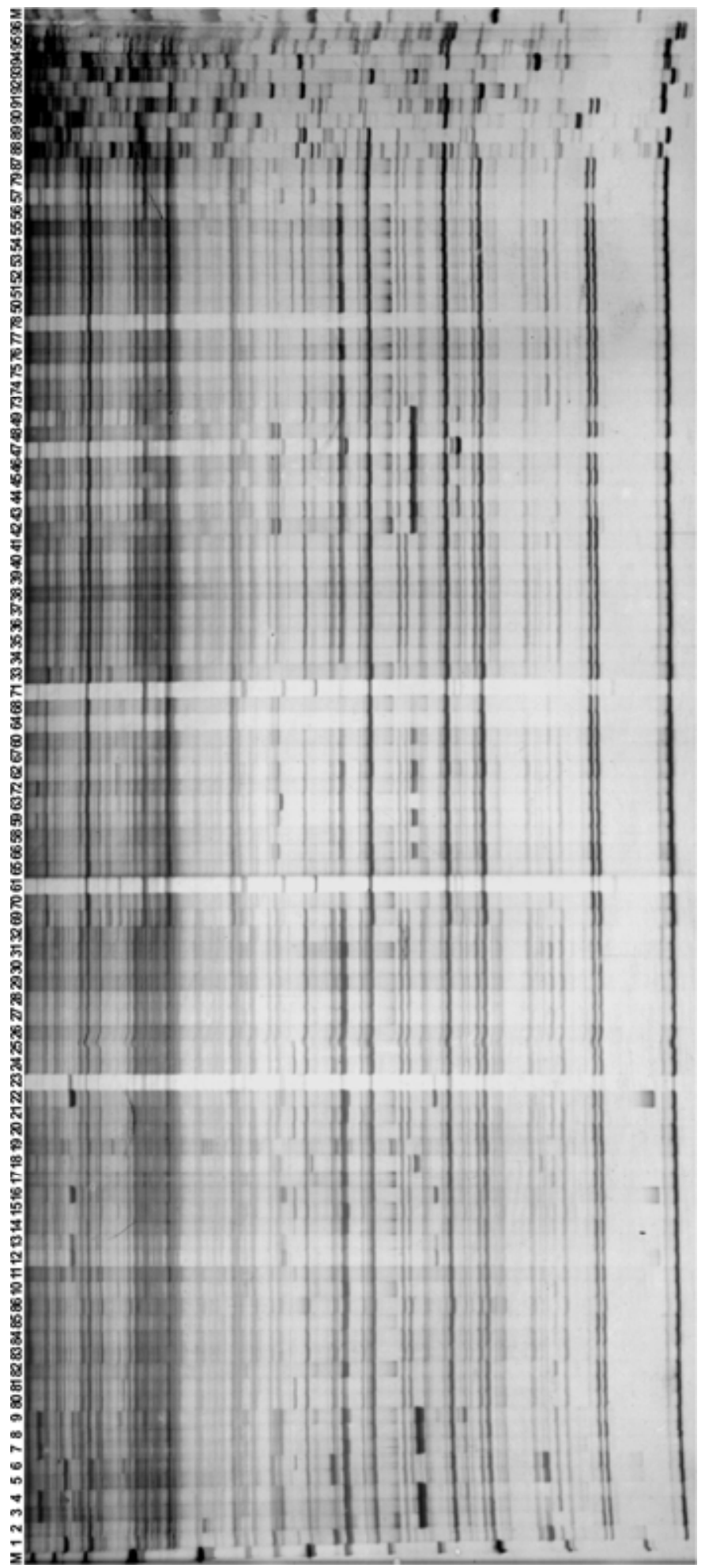

Fig. 2. Amplified fragment length polymorphism profiles generated with the primers $\mathrm{M}+\mathrm{T} / \mathrm{E}+\mathrm{G}$ of a collection of Xanthomonas axonopodis: the number assigned to each isolate of pv. passiflorae (1 to 87) and to other pathovars of $X$. axonopodis ( 88 to 96 ) is indicated at the left of each lane. $\mathrm{M}$ is a mixture of 100- and 25-bp DNA molecular size markers (Invitrogen). 
used as a template following the same PCR conditions as described for molecular diagnosis. Positive controls received bacterial colonies as PCR templates.

\section{RESULTS}

Bacterial identification and pathogenicity. Following the protocol of Starr and Stephens (26), the yellow extracts obtained from all the isolates showed a maximum absorbance at $443 \mathrm{~nm}$ and shoulders at 470 and $425 \mathrm{~nm}$, which are typical of xanthomonadins, confirming that all isolates belong to the genus Xanthomonas. The leaf lesions (minimum of $1.6 \mathrm{~cm}^{2}$ ) provoked by the artificial inoculations confirmed that all isolates were pathogenic.

Molecular diversity. All ERIC, BOX, and REP primer sets, as well as several combinations of AFLP selective primers, generated consistent molecular patterns for all 87 of the $X$. axonopodis pv. passiflorae isolates, and very distinct profiles for each

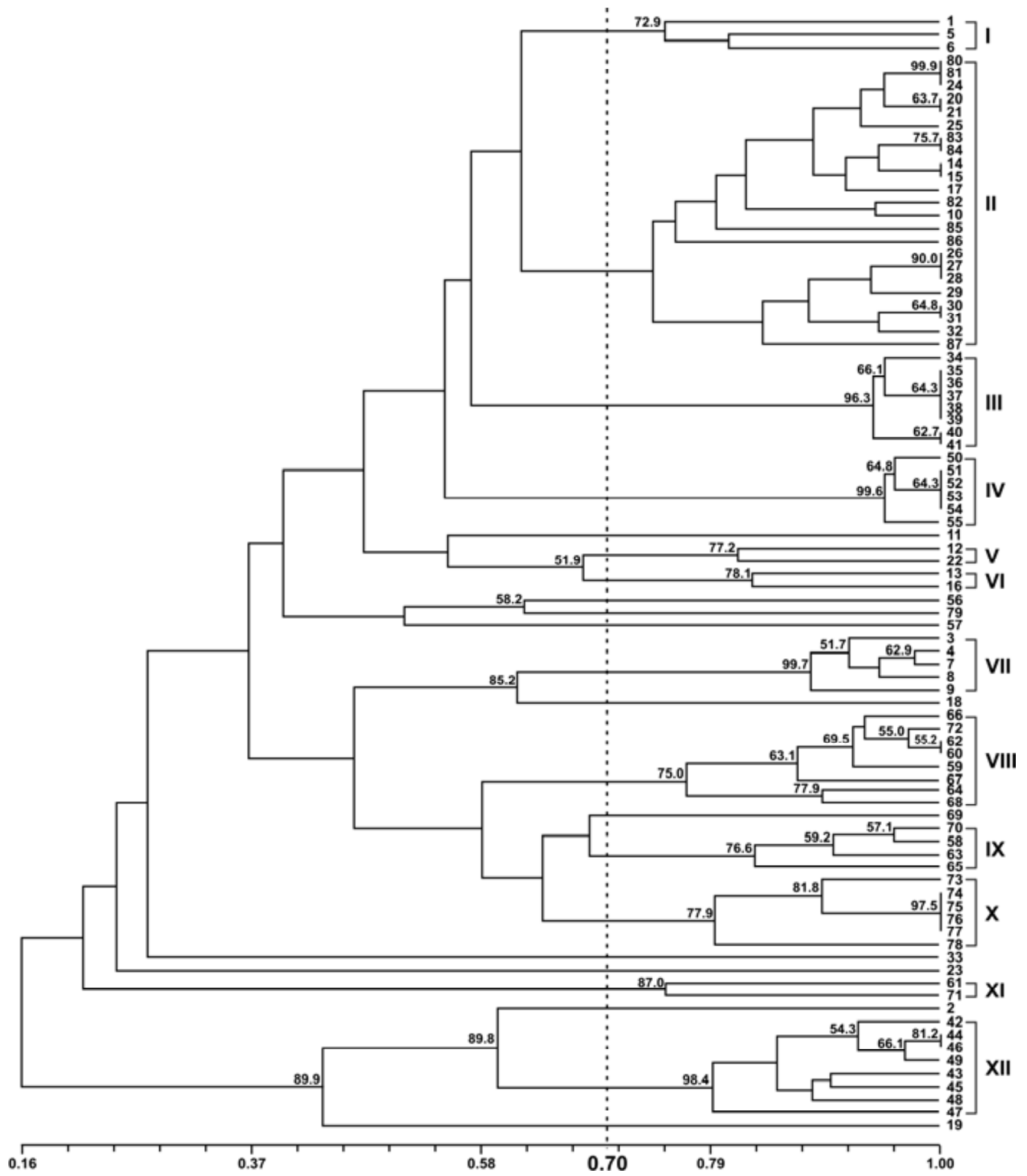

Fig. 3. Dendrogram generated by cluster analysis using unweighted pair-group method with arithmetical averages based on amplified fragment length polymorphism profiles of Xanthomonas axonopodis pv. passiflorae isolates (Table 1, 1 to 87). Bootstrap values are indicated at the branches and clusters were delineated at an arbitrary similarity level of 0.70 . The scale bar indicates the genetic similarities measured by the Jaccard's coefficient. 
of the pathovars. Although there was an agreement between repPCR and AFLP results, the rep-PCR fingerprints revealed a limited amount of polymorphic loci (31) within the pv. passiflorae isolates. Therefore, the rep-PCR technique was not useful to identify a significant clustering pattern (data not shown), because a high number of isolates need to be compared. However, this method was important to reveal that $X$. axonopodis pathovars were molecularly very distinct (Fig. 1).

Out of 408 AFLP loci obtained from nine selective primer combinations, 89 were polymorphic. The primer combinations $\mathrm{M}+0 / \mathrm{E}+\mathrm{AA}$ and $\mathrm{M}+\mathrm{CA} / \mathrm{E}+\mathrm{CG}$ revealed 15 polymorphic loci each, $\mathrm{M}+\mathrm{T} / \mathrm{E}+\mathrm{G}$ revealed 13 , and $\mathrm{M}+\mathrm{G} / \mathrm{E}+\mathrm{A}$ and $\mathrm{M}+\mathrm{G} / \mathrm{E}+\mathrm{T}$ revealed 10 and 9 , respectively. Nine loci were indicated by $\mathrm{M}+\mathrm{AG} /$ $\mathrm{E}+\mathrm{T}$, eight from $\mathrm{M}+\mathrm{A} / \mathrm{E}+\mathrm{G}$, six from $\mathrm{M}+\mathrm{T} / \mathrm{E}+\mathrm{C}$, and four from $\mathrm{M}+\mathrm{C} / \mathrm{E}+\mathrm{A}$. Fragments sizes varied from 90 to $880 \mathrm{bp}$ (Fig. 2).

Estimates of overall pair-wise genetic similarities between isolates generated by the Jaccard coefficient were 0.16 to 1.0 . With 0.7 as the minimum threshold for designating genetic simi- larity, 12 groups were formed as shown in the dendrogram generated from the UPGMA cluster analysis (Fig. 3). The cophenetic correlation - the correlation between the distances at which a pair of observations are joined in a dendrogram and the dissimilarity values for that pair-was 0.9255 , meaning that clustering was very successful in partitioning the data. The dendrogram shows the exclusive occurrence of isolates from some localities. For example, all isolates from localities $U$ and D were clustered into group II, and isolates from F, H, and G were clustered into groups III, IV, and XII, respectively. In contrast to the location-specific clustering of some isolates, those collected from A were clustered into two groups, I and VII.

The similarity analyses and resulting dendrograms supported the results of the AMOVA, which indicated considerable betweenlocality variation and less within-locality variation. In all, $\approx 50 \%$ of the total molecular variance was due to differences between localities, $36 \%$ was due to differences within the localities, and $14 \%$ of the variance was partitioned between the geographical states.
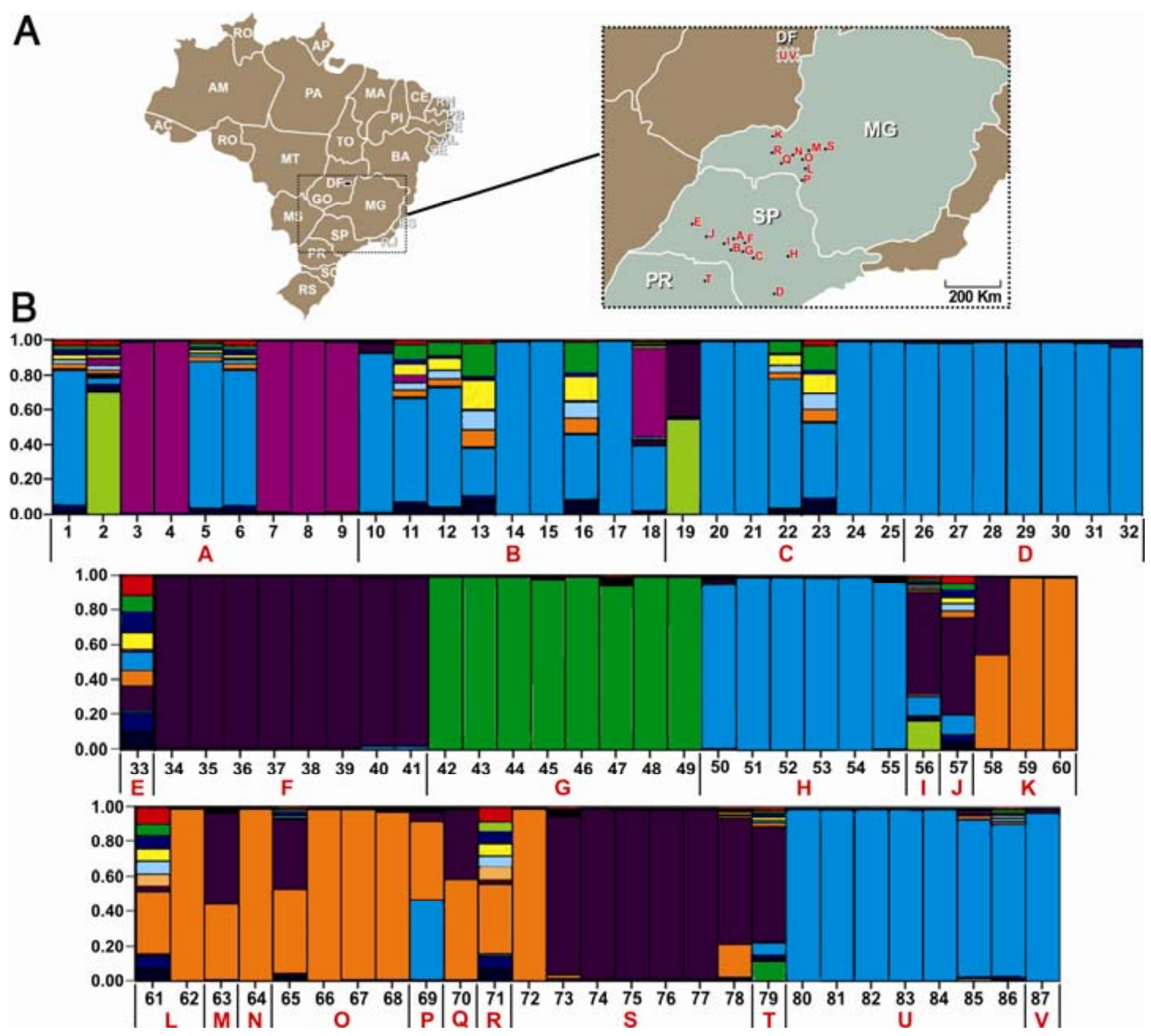

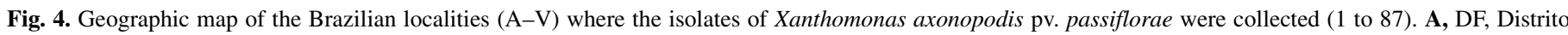

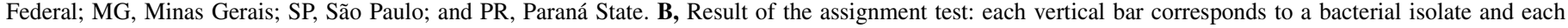

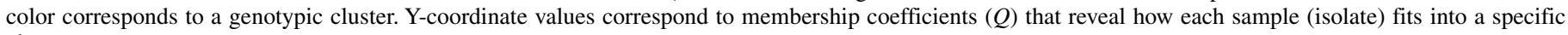
cluster. 
Molecular data were analyzed by the computer program Structure using Bayesian models to probabilistically assign each genotype to a genetically distinct cluster. Data were arranged using the number of localities (i.e., 22) (Fig. 4A, A to V) to complete the assigning task. The best $K$ value found according to the model described by Evano et al. (5) was 13, meaning that all 87 isolates were assigned to 13 clusters, which are represented by a color-coded bar graph shown in Figure 4B. These findings were very similar to the UPGMA results, because the number of groups in the dendrogram was 12 (Fig. 3).

In essence, the assignment test determined whether a cluster had a molecular genotype that was typical of the locality where samples originated (as in F) or whether it was divided among one or more different localities (as in the blue-colored cluster). The Ycoordinate values correspond to membership coefficients $(Q)$ that reveal how each sample (isolate) fits into a specific cluster (Fig. 4B).

The assignment test revealed that $\mathrm{A}, \mathrm{B}$, and $\mathrm{C}$ populations were genetically diverse. The populations of $\mathrm{D}, \mathrm{F}, \mathrm{G}, \mathrm{H}$, and $\mathrm{U}$, in contrast, were uniform (Fig. 4B). These results reflect those of the dendrogram obtained using the UPGMA algorithm. There was no genetic variation within 10 localities because just one isolate occurred in each. However, the assignment test showed that eight of those isolates were contained in different clusters $(Q \leq 66 \%)$. The remaining isolates (64 and 87) were contained in one single cluster with membership coefficients of $Q=98.3$ and $96.2 \%$, respectively (Fig. 4B).

Molecular diagnosis of $X$. axonopodis pv. passiflorae. The alignment of the fragment $(1,000 \mathrm{bp})$ of the 16S-23S rRNA intergenic spacer region showed the presence of an SNP within the pv. passiflorae sequence. Comparing the 12 ITS sequences, a $\mathrm{G}$ nucleotide was detected within the pv. passiflorae sequence instead of a $\mathrm{T}$ nucleotide that was detected in the other pathovars. The inner primer Xapas-Ri was designed to be specific to pv. passiflorae, with its $3^{\prime}$-terminal base positioned at the SNP, and a second deliberate mismatch introduced to enhance specificity (Fig. 5A). As expected, a larger amplicon of $641 \mathrm{bp}$ was produced in all pathovars because the primers Xapas-F and Xapas-Ro were designed to anneal to a conserved region of the ITS sequence; a second and smaller fragment of $520 \mathrm{bp}$ was amplified exclusively from all 87 isolates of the pv. passiflorae (Fig. 5B). In samples of our studies, the PCR-based method for the detection of pv. passiflorae described before (7) failed to detect isolates from different locations.
A

pv. passiflorae (5) pv. passiflorae (19) pv. passiflorae (43) pv. passiflorae $(80)$ pv. vesicatoria (88) pv. dieffenbachiae (89) pv. vitians (90) pv. allii (91) pv. malvacearum (92) pv. manihotis (93) pv. vasculorum (94) pv. phaseoli (95)

\section{Xapas-Ri}

CÄTATCGACGACCTTCGCTT ATCCCGACAGGCTCCACC, TTCGATCCCGACAGGCTCCACCAT TTCGATCCCGACAGGCTCCACCAT . . . AATGCATAGCTGCTGGAAGCGAACCC . . A TTCGATCCCGACAGGCTCCACCAT . . AATGCATAGCTGCTGGAAGCGAACCC . . TTCGATCCCGACAGGCTCCACCAT . . AATGCATAGCTGCTGGAAGCGAACCC. . TTCGATCCCGACAGGCTCCACCAT. . AATTCATAGCTGCTGGAAGCGAACCC. .

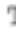
TTCGATCCCGACAGGCTCCACCAT. . . . AAT TCATAGCTGCTGGAAGCGAACCC. . TTCGATCCCGACAGGCTCCACCAT . . . AATTCATAGCTGCTGGAAGCGAACCC . . . ATGGCTTTAGAAAAACAATCTGGAA TTCGATCCCGACAGGCTCCACCAT . . . AATTCATAGCTGCTGGAAGCGAACCC . . . ATGGCTTTAGAAAAAAACAATCTGGAA. TTCGATCCCGACAGGCTCCACCAT . . . AATTCATAGCTGCTGGAAGCGAACCC . . . ATGGCTTTAGAAAAACAATCTGGGA TTCGATCCCGACAGGCTCCACCAT . . A.ATTCATAGCTGCTGGAAGCGAACCC . . . ATGGCTTTAGAAAAACAATCTGGAA. TTCGATCCCGACAGGCTCCACCAT . . A.ATTCATAGCTGCTAGAAGCGAACCC . . . ATGGCTTTAGAAAAAACA.ATCTGGA.

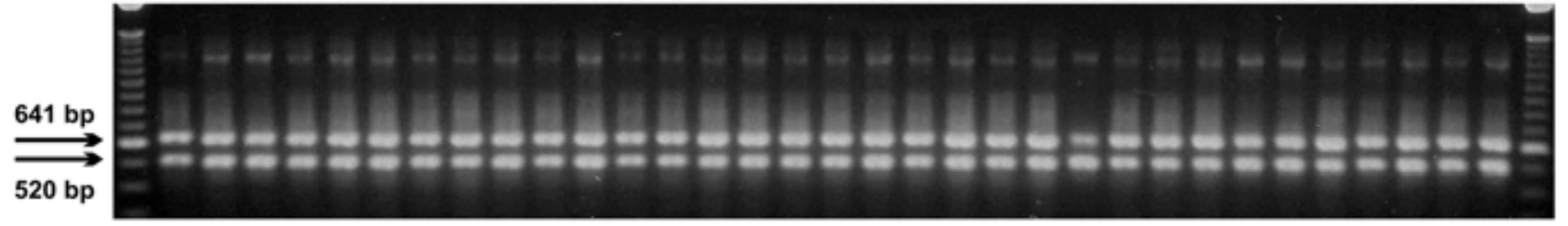

M 343536373839404142434445464748495051525354555657585960616263646566 M

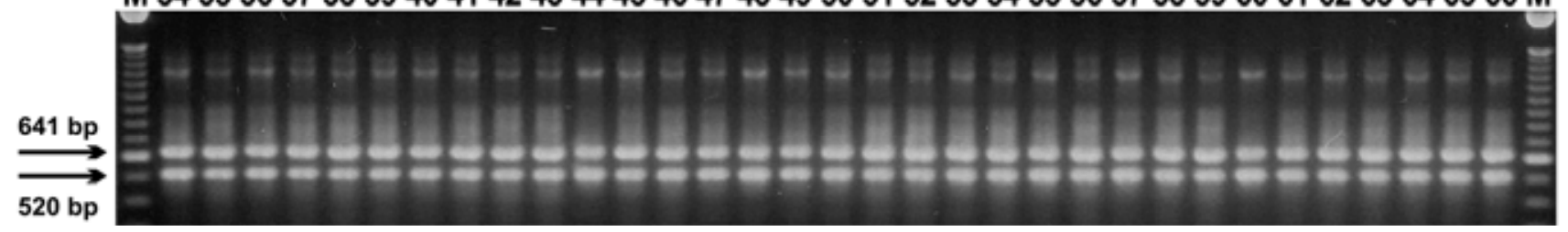

M 6768697071727374757677787980818283848586878889909192939495969798 M

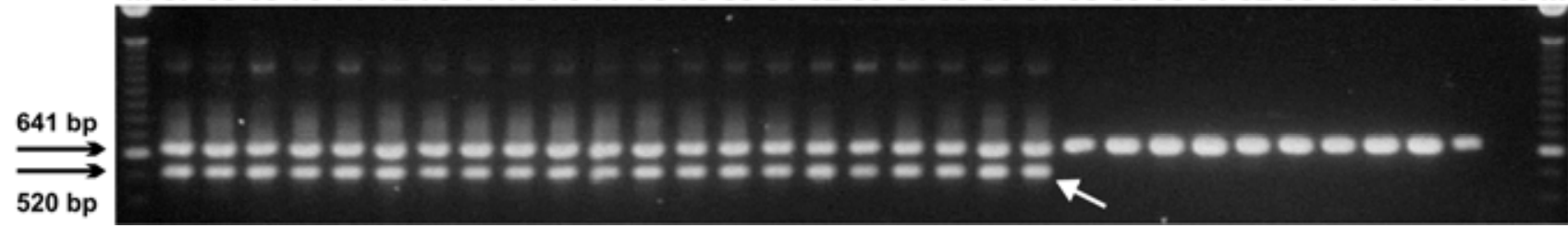

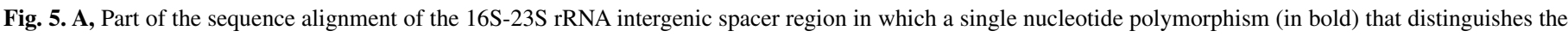

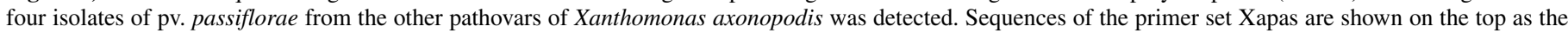

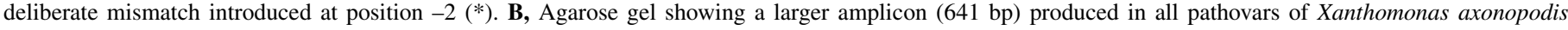

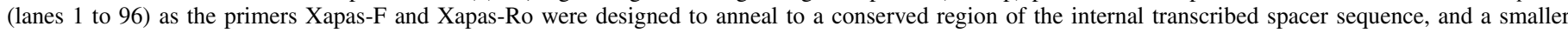

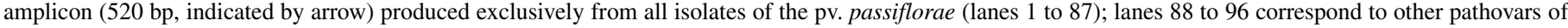

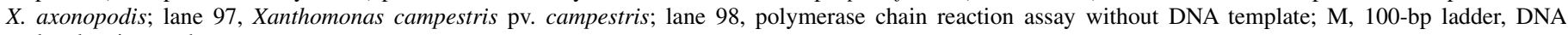
molecular size marker. 
Passion fruit plants started to show typical symptoms of infection 8 days after artificial bacterial inoculation, though on day five we were able to detect amplicons with the primer set (Xapas) in DNA extracted from a leaf segment proximal to the inoculation point. These amplicons were weak in relation to those produced in samples collected on days 12 and 19 from locations proximal or distal to the inoculation point. Over time, bacteria colonized the leaf and became increasingly abundant as PCR repeatedly revealed conspicuous bands from all plants (Fig. 6). The bacterial densities in infected plants were measured during the evaluation period. Average concentrations were $0.60 \times$ $10^{7} \mathrm{CFU} / \mathrm{g}$ on day $5,5.86 \times 10^{7} \mathrm{CFU} / \mathrm{g}$ on day 12 , and $14.31 \times$ $10^{7} \mathrm{CFU} / \mathrm{g}$ on day 19 . Neither symptoms nor colonies were detected in the control plant.

\section{DISCUSSION}

Genomic-based fingerprints have been used to identify pathovars and strains that were previously not distinguishable by other classification methods $(11,16,17)$. In the present study, we observed different DNA patterns for all nine pathovars of $X$. axonopodis revealed by rep-PCR and AFLP profiling (Figs. 1 and 2 ), reflecting the adaptation of bacteria to specific hosts.

We found a close association between the geographical origin of the 87 isolates of $X$. axonopodis pv. passiflorae and AFLPbased polymorphism; Restrepo et al. (24) reported a similar relationship for $X$. axonopodis pv. manihotis. There was a predominance of only a few clusters in most of the sample or production locations (Fig. 3). The assignment test provided important information on the genetic structure of the bacterial population and its relationship to pathogen migration. The blue-colored cluster, for example, was predominant in the localities B, C, D, H, $\mathrm{U}$, and $\mathrm{V}$, the latter two being geographically distant from the others. It suggests that the pathogen was disseminated through infected cuttings from a production area to the country's center. The test also indicated that some genotypes are more successful in their ability to colonize the orchards, particularly the ones colored in brown (predominant in F) and green (predominant in $\mathrm{G})$, though the respective locations are very close to genetically diverse areas (A and B). All of these data have important implications for disease control.

In contrast, $10 \%$ of the isolates were admixed $(13,16,18,23$, $33,56,57,61$, and 71), sharing their molecular profiles with several clusters. Each of these isolates was given a membership coefficient for each cluster where $Q<60 \%$, the sum of membership coefficients being 1. For example, the localities A and B were very diversified, with admixed isolates that probably migrated from neighboring areas and colonized the vines.

The high level of genomic diversity found among the bacterial isolates is possibly associated with the outcrossing behavior of

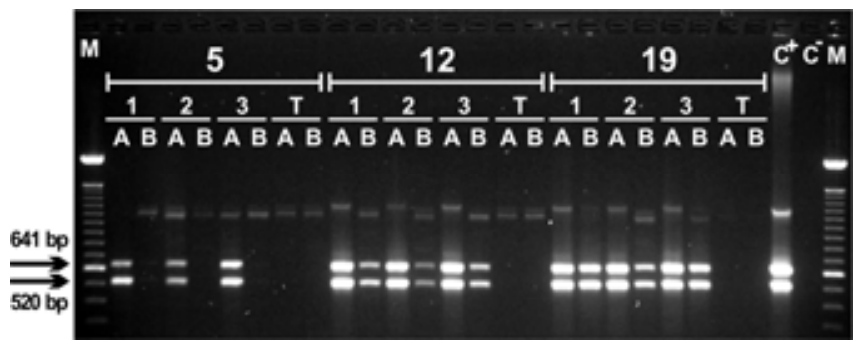

Fig. 6. Agarose gel showing the amplicons generated by polymerase chain reaction $(\mathrm{PCR})$ with the primer set Xapas and DNA extracted from passion fruit plants $(1,2$, and 3$)$ after 5,12 , and 19 days of inoculation with $X$. axonopodis pv. passiflorae; $\mathrm{M}, 100$-bp ladder, DNA molecular size marker; T, the control plant; A and B correspond to DNA extracted from leaf segments proximal and distal to the inoculation point, respectively; $\mathrm{C}^{+}$, positive control received bacterial colonies as the $\mathrm{PCR}$ template; $\mathrm{C}^{-}, \mathrm{PCR}$ assay without DNA template as a negative control. cultivated passion fruit. In Brazil, however, passion fruit is a recent crop and propagation of cultivated varieties is often through vegetative means. Therefore, pathogens at some localities are under less selection pressure, resulting in less diversification. Similar results were reported for Xylella fastidiosa when comparing SNP-based molecular profiles of two strains from the same host collected from distinct geographical areas, as well as from different hosts (30). A significant effect of geographic location on genetic diversity of Xanthomonas arborícola pv. juglandis, the cause of walnut blight, and $X$. translucens pv. graminis, which causes bacterial wilt in forage grasses, was detected by cluster analyses using AFLP markers $(13,16)$.

Our research investigated diversity in $X$. axonopodis $\mathrm{pv}$. passiflorae using an UPGMA-based dendrogram and an assigning test, as well as AMOVA. Similar conclusions can be drawn from the data obtained from different methods; for example, there was greater variability between different sample locations than within most of them. Similar results were reported for X. axonopodis pv. manihotis (24). Population studies such as this expand our current knowledge about pathogen dissemination and have important implications for disease control. Our data suggest that the dispersal of isolates is reduced and that dissemination occurs primarily through infected cuttings.

Molecular diagnostics of plant pathogens for disease management is gaining importance. Park et al. (21) designed a primer pair to amplify a sequence of the $h r p F$ gene to detect $X$. campestris pv. campestris but the ITS sequence was preferentially used to design primers for distinguishing Xanthomonas spp. and pathovars $(8,9)$ and detecting the pathogen in cultivated plants $(3)$. In the present work, a set of primers (Xapas) was shown to efficiently detect all isolates of $X$. axonopodis pv. passiflorae as well as the presence of the pathogen in plant tissues even before outward symptoms were apparent. As far as we know, this is the first report on the use of an assigning test to provide information on the genetic structure of a bacterial population, and to utilize a primer set specially designed for bacterial diagnosis based on a SNP-anchored approach (31).

\section{ACKNOWLEDGMENTS}

We thank Fundação de Amparo a Pesquisa do Estado de São Paulo (FAPESP, Brazil) for financial support, Coordenação de Aperfeiçoamento de Pessoal de Nível Superior (CAPES, Brazil) for a fellowship to C. F. Munhoz, and C. A. de Oliveira for excellent technical assistance.

\section{LITERATURE CITED}

1. Ausubel, F. M., Brent, R., Kingston, R. E., Moore, D. D., Seidmam, J. G., Smith, J. A., and Struhl, K., eds. 1992. Short Protocols in Molecular Biology: A Compendium of Methods from Current Protocols in Molecular Biology, 2nd ed. Greene Publishing Associates, New York.

2. Carneiro, M. S., Camargo, L. E. A., Coelho, A. S. G., Vencovsky, R., Leite, R. P., Stenzel, N. M., and Vieira, M. L. C. 2002. RAPD-based genetic linkage maps of yellow passion fruit (Passiflora edulis Sims. f. flavicarpa Deg.). Genome. 45:670-678.

3. Cubero, J., and Graham, J. H. 2002. Genetic relationship among worldwide strains of Xanthomonas causing canker in citrus species and design of new primers for their identification by PCR. Appl. Environ. Microbiol. 68:1257-1264.

4. Dellaporta, S. L., Wood, J., and Kicks, J. B. 1983. A plant DNA minipreparation: version II. Plant Mol. Biol. Rep. 1:19-20.

5. Evano, G., Regnaut, S., and Goudet, J. 2005. Detecting the number of clusters of individuals using the software structure: A simulation study. Mol. Ecol. 14:2611-2620.

6. Gonçalves, E. R., and Rosato, Y. B. 2000. Genotypic characterization of xanthomonad strains isolated from passion fruit plants (Passiflora spp.) and relatedness to different Xanthomonas species. Int. J. Syst. Evol. Microbiol. 50:811-821.

7. Gonçalves, E. R., and Rosato, Y. B. 2002. Detecção de Xanthomonas axonopodis pv. passiflorae utilizando-se sondas de DNA e "primers" específicos. Summa Phytopathol. 28:20-27.

8. Gonçalves, E. R., and Rosato, Y. B. 2002. Phylogenetic analysis of 
Xanthomonas species based upon 16S-23S rDNA intergenic spacer sequences. Int. J. Syst. Evol. Microbiol. 52:355-361.

9. Hendson, M., Purcell, A. H., Chen, D., Smart, C., Guilhabert, M., and Kirkpatrick B. 2001. Genetic diversity of Pierce's disease strains and other pathotypes of Xylella fastidiosa. Appl. Environ. Microbiol. 67:895-903.

10. Honeycutt, R. J., Sobral, B. W. S., and McClelland, M. 1995. tRNA intergenic spacers reveal polymorphisms diagnostic for Xanthomonas albilineans. Microbiology 141:3229-3239.

11. Hu, J., Zhang, Y., Qian, W., and He, C. 2007. Avirulence gene and insertion element-based RFLP as well as RAPD markers reveal high levels of genomic polymorphism in the rice pathogen Xanthomonas oryzae pv. oryzae. Syst. Appl. Microbiol. 30:587-600.

12. Jaccard, P. 1908. Nouvelles recherches sur la distribution florale. Bull. Soc. Vaud. Sci. Nat. 44:223-270.

13. Kölliker, R., Kraehenbuehl, R., Boller, B., and Widmer, F. 2006. Genetic diversity and pathogenicity of the grass pathogen Xanthomonas translucens pv. graminis. Syst. Appl. Microbiol. 29:109-119.

14. Kosawang, C., Smitamana, P., Toojinda, T., Nilpanit, N., and Sirithunya, P. 2006. Amplified fragment length polymorphism fingerprinting differentiates genetic diversity of Xanthomonas oryzae pv. oryzae from Northern Thailand. J. Phytopathol. 154:550-555.

15. Lopes, R., Lopes, M. T. G., Carneiro, M. S., Matta, F. P., Camargo, L. E. A., and Vieira, M. L. C. 2006. Linkage and mapping of resistance genes to Xanthomonas axonopodis pv. passiflorae in yellow passion fruit. Genome 49:17-29.

16. Loreti, S., Gallelli, A., Belisario, A., Wajnberg, E., and Corazza, L. 2001. Investigation of genomic variability of Xanthomonas arboricola pv. juglandis by AFLP analysis. Eur. J. Plant. Pathol. 107:583-591.

17. Louws, F. J., Fulbright, D. W., Stephens, C. T., and Bruijn, F. J. 1994. Specific genomic fingerprints of phytopathogenic Xanthomonas and Pseudomonas pathovars and strains generated with repetitive sequences and PCR. Appl. Environ. Microbiol. 60:2286-2295.

18. Massol-Deya, A. A., Odelson, D. A., Hickey, R. F., and Tiedje, J. M. 1995. Bacterial community fingerprinting of amplified $16 \mathrm{~S}$ and $16 \mathrm{~S}-23 \mathrm{~S}$ ribosomal DNA gene sequences and restriction endonuclease analysis (ARDRA). Pages 1-8 in: Molecular Microbial Ecology Manual. A. D. L. Akkermans, J. D. Van Elsas, and F. J. De Bruijn, eds. Kluwer Academic Publishers, Dordrecht., The Netherlands.

19. Oliveira, E. J., Vieira, M. L. C., Garcia, A. A. F., Munhoz, C. F., Margarido, G. R. A., Consoli, L., Matta, F. P., Moraes, M. C., Zucchi, M. I., and Fungaro, M. H. P. 2008. An integrated molecular map of yellow passion fruit based on simultaneous maximum-likelihood estimation of linkage and linkage phases. J. Am. Soc. Hortic. Sci. 133:35-41.
20. Oliveira, V. M., Manfio, G. P., Coutinho, H. L. C., Keijzer-Wolters, A. C. and Elsas, J. D. V. 2006. A ribosomal RNA gene intergenic spacer based PCR and DGGE fingerprinting method for the analysis of specific rhizobial communities in soil. J. Microbiol. Methods 64:366-379.

21. Park, Y. J., Lee, B. M., Ho-Hahn, J., Lee, G. B., and Park, D. S. 2004. Sensitive and specific detection of Xanthomonas campestris pv. campestris by PCR using species specific primers based on hrpF gene sequences. Microbiol. Res. 159:419-423.

22. Pereira, A. L. G. 1969. Uma nova doença bacteriana do maracujá (Passiflora edulis, Sims) causada por Xanthomonas passiflorae $\mathrm{n}$. sp. Arq. Inst. Biol. 36:163-174.

23. Pritchard, J. K., Matthew, S., and Donnelly, P. 2000. Inference of population structure using multilocus genotype data. Genetics 155:945959.

24. Restrepo, S., Vélez, C. M., and Verdier, V. 2000. Measuring the genetic diversity of Xanthomonas axonopodis pv. manihotis within different fields in Colombia. Phytopathology 90:683-690.

25. Rohlf, F. J. 2000. NTSYS-pc. Version 2.1d. Numerical Taxonomy and Multivariate Analysis System. Exeter Software, Setauket, NY.

26. Starr, M. P., and Stephens, W. L. 1964. Pigmentation and taxonomy of the genus Xanthomonas. J. Bacteriol. 87:293-302.

27. Valverde, A., Hubert, T., Stolov, A., Dagar, A., Kopelowitz, J., and Burdman, S. 2007. Assessment of genetic diversity of Xanthomonas campestris pv. campestris isolates from Israel by various DNA fingerprinting techniques. Plant Pathol. 56:17-25.

28. Vieira, M. L. C., and Carneiro, M. S. 2005. Passiflora spp. passionfruit. Pages 436-453 in: Biotechnology of Fruit and Nut Crops. R. E. Litz, ed. CABI Publishing, Oxford

29. Vos, P., Hogers, R., Bleeker, M., Reijans, M., Vandelee, T., Hornes, M. Frijters, A., Pot, J., Peleman, J., Kuiper, M., and Zabeau, M. 1995. AFLP: A new technique for DNA fingerprinting. Nucleic Acids Res. 23:44074414.

30. Wickert, E., Machado, M. A., and Lemos, E. G. M. 2007. Evaluation of the genetic diversity of Xylella fastidiosa strains from citrus and coffee hosts by single-nucleotide polymorphism markers. Phytopathology 97:1543-1549.

31. Ye, S., Dhillon, S., Ke, X., Collins, A. R., and Day, I. N. M. 2001. An efficient procedure for genotyping single nucleotide polymorphisms. Nucleic Acids Res. 29:e88. Online publication/10.1093/nar/29.17.e88.

32. Zerbini, F. M., Otoni, W. C., and Vieira, M. L. C. 2008. Passionfruit. Pages 213-234 in: A Compendium of Transgenic Crop Plants-Tropical and Subtropical Fruit and Nuts. C. Kole and T. C. Hall, eds. WileyBlackwell, Berlin. 